\title{
Insulin-Like Growth Factor Axis in Pregnancy and Gestational Diabetes Mellitus
}

\author{
K. ANDERLOVÁ ${ }^{1,4}$, A. CINKAJZLOVÁ ${ }^{2,3}$, P. ŠIMJÁK ${ }^{1}$, J. KLOUČKOVÁ ${ }^{2,3}$, \\ H. KRATOCHVÍLOVÁ ${ }^{2,3}$, Z. LACINOVÁ ${ }^{3,4}$, P. KAVÁLKOVÁ ${ }^{2}$, H. KREJČÍ ${ }^{1,4}$, \\ M. MRÁZ ${ }^{2,5}$, A. PAŘíZEK ${ }^{1}$, M. HALUZÍK ${ }^{2,3,5,6}$, M. KRŠEK ${ }^{4,7}$
}

${ }^{1}$ Gynaecology and Obstetrics Department, First Faculty of Medicine, Charles University and General University Hospital, Prague, Czech Republic, ${ }^{2}$ Institute of Medical Biochemistry and Laboratory Diagnostics, First Faculty of Medicine, Charles University and General University Hospital, Prague, Czech Republic, ${ }^{3}$ Centre for Experimental Medicine, Institute for Clinical and Experimental Medicine, Prague, Czech Republic, ${ }^{4}$ Third Department of Medicine, First Faculty of Medicine, Charles University and General University Hospital, Prague, Czech Republic, ${ }^{5}$ Department of Diabetes, Diabetes Centre, Institute for Clinical and Experimental Medicine, Prague, Czech Republic, ${ }^{6}$ Department of Obesitology, Institute of Endocrinology, Prague, Czech Republic, ${ }^{7}$ Second Department of Internal Medicine, Third Faculty of Medicine, Charles University and University Hospital Královské Vinohrady, Prague, Czech Republic

Received November 24, 2018

Accepted June 10, 2019

Epub Ahead of Print August 19, 2019

\section{Summary}

The insulin-like growth factor (IGF) is involved in the regulation of growth and metabolism. The aim of this study was to determine selected parameters of IGF system at systemic and local levels [subcutaneous (SAT) and visceral adipose tissue (VAT)] to assess its possible role in gestational diabetes mellitus (GDM). 37 pregnant women (21 with GDM and 16 without GDM) and 15 age-matched non-pregnant females were included in the study. Blood samples were taken in 28-32 and 36-38 weeks of gestation and 6-12 months after delivery. SAT and VAT samples were obtained during delivery or surgery. Compared with nonpregnant women, serum IGF-1 and IGFBP-3 were increased in both groups of pregnant women. IGF-2 was elevated only in GDM women from 36 weeks of gestation culminating 6 months after delivery $(p=0.003)$. Serum IGFBP-3 was increased and IGFBP-4 decreased in GDM women vs. pregnant women without GDM during the whole study (IGFBP-3: $p<0.001$ for GDM vs. non-GDM; IGFBP-4: $p=0.004$ for GDM vs. non-GDM). Pregnant women with GDM had decreased mRNA expression of IGF-1, IGF-1R and IGF-2R and IGFBP-4 in VAT and IGF-1R in SAT compared to pregnant women without GDM. Changes in local activity of IGF are associated with the development of GDM.

\section{Key words}

Insulin-like growth factor - IGF-binding proteins • Gestational diabetes mellitus $\bullet$ Insulin sensitivity • Adipose tissue

\section{Corresponding author}

M. Kršek, Second Department of Medicine, Third Faculty of Medicine, Charles University, Šrobárova 1150/50, 10034 Prague 10, Czech Republic. E-mail: michal.krsek@fnkv.cz

\section{Introduction}

The system of insulin-like growth factors (IGF) and their binding proteins (IGFPBs) consists of IGF-1, IGF-2 and seven high-affinity binding proteins IGFBP-1 - IGFBP-7 and plays multiple roles in human physiology with regulation of growth, proliferation and differentiation and also metabolic activities belonging to most important ones. Both IGFs can act via type 1 IGF-1 receptor (IGF-1R) and type 2 IGF-2 receptor (IGF-2R). IGF-1R is a heterodimer with similar structure to insulin receptor, which mediates most of proliferative and metabolic actions of IGFs. IGF-2R is identical with the mannose-6-phosphate receptor and is thought to have 
a role in IGF-2 clearance. The family of high affinity binding proteins modulates in a differential manner the bioactivity and bioavailability of IGFs with some of the members supposedly exerting their own direct biological effects (Chan and Spencer 1997).

Regulation of glucose metabolism is one of the most important metabolic roles of the system of IGFs and their binding proteins. IGF-1 and to a certain degree also IGF-2 increase insulin sensitivity and improve glucose metabolism through the action at IGF-1R and also through synergistic effect with insulin at insulin receptor (Moses et al. 1996, Mauras and Haymond 2005). IGF-2 is highly expressed during embryogenesis. It is believed that major role of IGF-2 is to stimulate growth during fetal life as opposed to IGF-1 that is the main growth stimulator after birth (Livingstone 2013). Moreover, the IGF system participates in the control of cell proliferation and differentiation including adipocytes and monocytes thus potentially affecting the inflammatory processes and adipogenesis, which might play a role in the development of insulin-resistance (Torres and Aleman 2005, Bluher et al. 2005, Wabitsch et al. 1995). IGFBP-1 modulates the bioavailability of IGF-1 by its binding. Systemic levels of IGFBP-1 reflect its production in the liver, which is inhibited by insulin in portal blood. IGFBP-3 is the main IGF binding protein which is largely saturated by IGF and IGF-1 bound to IGFBP-3 serves as the circulating pool of IGF (Rajpathak et al. 2009).

Gestational diabetes mellitus (GDM) belongs to the most important complications of pregnancy affecting approximately $15 \%$ of pregnant women (Zhu and Zhang 2016). Its incidence is increasing similarly to that of type 2 diabetes (Chen et al. 2011). GDM is associated with multiple gestational complications, including macrosomia, shoulder dystocia, stillbirth, neonatal hypoglycemia and respiratory distress (Langer et al. 2005). Patients with history of gestational diabetes have increased risk for metabolic disorders and type 2 diabetes in later life (Catalano et al. 2003).

The pathogenesis of GDM has not been fully elucidated so far; however, beta-cell dysfunction and failure of insulin secretion to compensate for insulin resistance induced by pregnancy are important contributing factors (Buchanan and Xiang 2005). Since the system of IGF and their binding proteins plays a role in regulation of glucose metabolism and insulin sensitivity (Holt et al. 2003), it is plausible to suggest that derangements of this system could also contribute to the pathogenesis of GDM and related complications. Studies addressing changes in the IGF system in GDM have dealt mainly with serum concentration of its particular components (Qiu et al. 2005). We hypothesized that the activity of the IGF system at the local level in adipose tissue could also participate in the pathogenesis of GDM. To this end, our study was designed to assess the effect of pregnancy and gestational diabetes mellitus on both systemic levels of IGFs and IGFBPs and on mRNA expression of IGFs and IGFBPs in adipose tissue.

\section{Methods}

\section{Study subjects}

Thirty-seven pregnant women (21 pregnant women with GDM and 16 pregnant women without GDM) and 15 non-pregnant women without diabetes mellitus indicated to gynecological surgery for benign ovarian tumors, uterine fibroids or other non-inflammatory and non-cancerous diseases were included in the study. GDM was diagnosed via $75 \mathrm{~g}$, 2-hour oral glucose tolerance test using IADPSG criteria between 24 and 28 weeks of gestation (International association of diabetes and pregnancy study groups consensus panel 2010). Written informed consent was signed by each subject and the studies were approved by the Human Ethics Review Board, First Faculty of Medicine and General University Hospital, Prague, Czech Republic. Women diagnosed with gestational diabetes received dietary counseling and underwent diabetologic surveillance. In one case insulin treatment had to be initiated at 33 weeks of gestation to ensure appropriate glucose control.

\section{Blood and tissue sampling}

In pregnant females, clinical examination was performed and blood samples were taken at 28 to 32 weeks of gestation (visit $1-\mathrm{V} 1$ ), 36 to 38 weeks of gestation (visit $2-\mathrm{V} 2$ ) and 6 to 12 months after delivery (visit 3 - V3). In the group of non-pregnant women, a single clinical examination and blood drawing was performed before the laparoscopic operation.

Blood samples were taken after an overnight fasting and centrifuged for $10 \mathrm{~min}$ at $3,000 \mathrm{xg}$ within $30 \mathrm{~min}$ after withdrawal. Serum or plasma aliquots were subsequently stored at $-80^{\circ} \mathrm{C}$.

Adipose tissue biopsy from visceral and subcutaneous adipose tissue was taken during cesarean section in pregnant women and during elective laparoscopy in non-pregnant females. Adipose tissue were immediately placed in the RNAlater ${ }^{\circledR}$ solution (Ambion ${ }^{\circledR}$ - Invitrogen, Carlsbad, California, USA) and were stored at $-80^{\circ} \mathrm{C}$. 
All samples were taken at the Gynaecology and Obstetrics Department, First Faculty of Medicine and General University Hospital, Prague, Czech Republic.

\section{Hormonal and biochemical assays}

Serum IGF-1 levels were measured by commercial EASIA kit (DIAsource ImmunoAssays S.A., Neuve, Belgium) with sensitivity $7.8 \mathrm{ng} / \mathrm{ml}$. Serum IGF-2 levels were measured by commercial RIA kit (DIAsource ImmunoAssays S.A., Neuve, Belgium) with sensitivity $0.1 \mathrm{ng} / \mathrm{ml}$. Serum levels of IGFBP proteins were measured by multiplex assay MILLIPLEX MAP Human IGF Binding Protein Magnetic Bead Panel - Metabolism Multiplex Assay (Merck KGaA, Darmstadt, Germany). Sensitivity for IGFBP-1 was $0.01 \mathrm{ng} / \mathrm{ml}$, for IGFBP-3 $0.12 \mathrm{ng} / \mathrm{ml}$, for IGFBP-4 $0.69 \mathrm{ng} / \mathrm{ml}$, for IGFBP-6 $0.07 \mathrm{ng} / \mathrm{ml}$ and for IGFBP-7 $0.04 \mathrm{ng} / \mathrm{ml}$. IGFBP-2 and IGFBP-5 were under detection limit of the method used.

Insulin and leptin were measured by MILLIPLEX MAP Human Adipokine Magnetic Bead Panel 2 (Merck KGaA, Darmstadt, Germany). Sensitivity for insulin was $3.8 \mathrm{pg} / \mathrm{ml}$ and for leptin $19 \mathrm{pg} / \mathrm{ml}$. The intra- and interassay variabilities for all assays were between 5.0 and $10.0 \%$.

Biochemical parameters (urea, creatinine, uric acid, total bilirubin, alanine aminotransferase (ALT), aspartate aminotransferase (AST), $\gamma$-glutamyltransferase (GGT), alkaline phosphatase (ALP), glycated hemoglobin $-\mathrm{HbA}_{1 \mathrm{c}}$, HDL cholesterol, total cholesterol, triglycerides) were measured and LDL cholesterol was calculated at the Institute of Medical Biochemistry and Laboratory Diagnostics, First Faculty of Medicine and General University Hospital, Prague, Czech Republic by standard laboratory methods.

\section{Quantitative real-time PCR}

Samples of adipose tissue were homogenized on MagNA Lyser Instrument (Roche Diagnostics GmbH, Mannheim, Germany). Total RNA was extracted on MagNA Pure instrument using Magna Pure Compact RNA Isolation kit (tissue) (Roche Diagnostics GmbH, Mannheim, Germany). RNA concentration was determined from the absorbance at $260 \mathrm{~nm}$ on NanoPhotometer (Implen, München, Germany). Reverse transcription was performed using random primers according to the manufacturer's protocol of the HighCapacity cDNA Reverse Transcription Kits (Applied Biosystems, Foster City, CA, USA). Input amount of RNA was $250 \mu \mathrm{g}$ per reaction. Gene expression was performed on a 7500 Real-Time PCR System (Applied Biosystems, Foster City, CA, USA). For reaction, a mix of TaqMan ${ }^{\circledR}$ Universal PCR Master Mix II, NO AmpErase ${ }^{\circledR}$ UNG (Applied Biosystems, Foster City, CA, USA), nuclease-free water (Fermentas Life Science, Vilnius, Lithuania) and specific TaqMan ${ }^{\circledR}$ Gene Expression Assays (Applied Biosystems, Foster City, CA, USA) were used. Beta 2 microglobulin (B2M) was applied as an endogenous reference. The formula $2^{\text {-ddCt }}$ was used to calculate relative gene expression.

\section{Statistical analysis}

Statistical analysis was performed and graphs were drawn using SigmaPlot 13.0 (SPSS Inc., Chicago, IL, USA). Results are expressed as means \pm standard error of the mean (SEM). One way ANOVA/One way RM ANOVA followed by Holm-Sidak test, One way ANOVA on Ranks/One way RM ANOVA on Ranks followed by Dunn's method, unpaired $t$-test or MannWhitney Rank Sum Test, paired $t$-test or Wilcoxon Signed-Rank were used for the assessment of intergroup differences, as appropriate. Spearman or Pearson correlation test was used to assess the association of serum levels of IGF-axis components and measured parameters. Baseline results of non-pregnant and all pregnant women were used for correlation analyses. Statistical significance was assigned to $\mathrm{p}<0.05$.

\section{Results}

The effect of pregnancy and gestational diabetes mellitus on biochemical parameters

The age of women in all three groups was comparable (Table 1). The BMI of the non-pregnant women $\left(22.7 \pm 0.8 \mathrm{~kg} / \mathrm{m}^{2}\right)$ and pre-pregnancy BMI of women with $\left(25.4 \pm 1.1 \mathrm{~kg} / \mathrm{m}^{2}\right)$ and without gestational diabetes $\left(24.0 \pm 1.1 \mathrm{~kg} / \mathrm{m}^{2}\right)$ did not significantly differ $(\mathrm{p}=0.285)$.

Differences in line with physiological changes in pregnancy including lower levels of creatinine, uric acid and total bilirubin and higher levels of total cholesterol and triglycerides were found between the non-pregnant control group and both groups of pregnant women at 28 to 32 weeks of gestation. Pregnant women with GDM had lower total bilirubin, total cholesterol, triglycerides and LDL cholesterol compared to the ones without GDM (Table 1).

All studied biochemical characteristics of the subjects in 36 to 38 weeks of gestation followed the course observed at V1. After delivery, higher ALT and AST levels were seen between non-pregnant women and pregnant women (Table 1). 
Table 1. Biochemical parameters: the influence of pregnancy and gestational diabetes mellitus.

\begin{tabular}{|c|c|c|c|c|c|c|c|}
\hline & $\begin{array}{c}\text { Non- } \\
\text { pregnant } \\
\text { women }\end{array}$ & $\begin{array}{c}\text { Pregnant } \\
\text { women with } \\
\text { GDM (V1) }\end{array}$ & $\begin{array}{c}\text { Pregnant } \\
\text { women with } \\
\text { GDM (V2) }\end{array}$ & $\begin{array}{c}\text { Pregnant } \\
\text { women with } \\
\text { GDM (V3) }\end{array}$ & $\begin{array}{c}\text { Pregnant } \\
\text { women } \\
\text { without } \\
\text { GDM (V1) }\end{array}$ & $\begin{array}{c}\text { Pregnant } \\
\text { women } \\
\text { without } \\
\text { GDM (V2) }\end{array}$ & $\begin{array}{c}\text { Pregnant } \\
\text { women } \\
\text { without } \\
\text { GDM (V3) }\end{array}$ \\
\hline Number(n) & 15 & 21 & --- & --- & 16 & --- & --- \\
\hline Age (year) & $36.2 \pm 0.52$ & $36.2 \pm 0.9$ & --- & -- & $34.5 \pm 1.0$ & --- & --- \\
\hline Body mass index $\left(\mathrm{kg} / \mathrm{m}^{2}\right)$ & $22.7 \pm 0.8$ & $28.1 \pm 1.0$ & $29.1 \pm 0.9^{1}$ & --- & $27.5 \pm 1.1$ & $28.9 \pm 1.3^{1}$ & --- \\
\hline $\mathrm{HbAlc}(\mathrm{mmol} / \mathrm{mol})$ & $32.7 \pm 1.3$ & $32.1 \pm 0.9$ & $35.1 \pm 1.0^{1}$ & $35.0 \pm 0.9^{2}$ & $31.6 \pm 0.9$ & $34.5 \pm 1.2^{1}$ & $35.1 \pm 0.8^{1}$ \\
\hline Creatinine (mmol/l) & $66.9 \pm 2.1$ & $47.7 \pm 1.5^{*}$ & $50.5 \pm 2.42 *$ & $65.6 \pm 1.7^{1,2}$ & $51.3 \pm 2.7 *$ & $52.6 \pm 2.7^{*}$ & $71.1 \pm 3.1^{1,2}$ \\
\hline Uric acid (mmol/l) & $259.2 \pm 13.5$ & $205 \pm 8.0 *$ & $243 \pm 11.1^{1}$ & $290 \pm 13.6^{1,2}$ & $204 \pm 15.1^{*}$ & $255 \pm 13.0^{1}$ & $265 \pm 18.1^{1}$ \\
\hline Urea $(\mathrm{mmol} / \mathrm{l})$ & $3.92 \pm 0.27$ & $3.09 \pm 0.16^{*}$ & $3.28 \pm 0.21$ & $5.28 \pm 0.27^{*, 1,2}$ & $2.77 \pm 0.12 *$ & $3.14 \pm 0.10$ & $4.88 \pm 0.29^{1,2}$ \\
\hline Total bilirubin ( $\mathrm{mmol} / \mathrm{l})$ & $12.07 \pm 1.36$ & $4.18 \pm 0.49 *$ & $4.58 \pm 0.59 *$ & $9.47 \pm 1.12^{1,2}$ & $5.29 \pm 0.47^{\mathrm{x}, *}$ & $6.55 \pm 0.95^{*}$ & $12.34 \pm 1.85^{1,2}$ \\
\hline Total cholesterol (mmol/l) & $4.44 \pm 0.31$ & $5.96 \pm 0.28^{*}$ & $6.70 \pm 0.32 *$ & $4.44 \pm 0.27^{1,2}$ & $7.32 \pm 0.33^{\mathrm{x}, *}$ & $7.704 \pm 0.41 *$ & $5.14 \pm 0.36^{1,2}$ \\
\hline Triglycerides $(\mathrm{mmol} / \mathrm{l})$ & $0.61 \pm 0.09$ & $1.93 \pm 0.24 *$ & $2.85 \pm 0.24^{*, 1}$ & $1.00 \pm 0.15^{1,2}$ & $2.49 \pm 0.22^{\mathrm{x}, *}$ & $2.69 \pm 0.25^{*}$ & $0.81 \pm 0.08^{1,2}$ \\
\hline LDL cholesterol (mmol/l) & $2.62 \pm 0.29$ & $3.11 \pm 0.25$ & $3.10 \pm 0.24$ & $2.32 \pm 0.22^{1,2}$ & $4.03 \pm 0.20^{\mathbf{x}, *}$ & $3.88 \pm 0.26^{\mathbf{x}}$ & $2.99 \pm 0.28^{1,2}$ \\
\hline HDL cholesterol $(\mathrm{mmol} / \mathrm{l})$ & $1.53 \pm 0.28$ & $2.11 \pm 0.09$ & $2.20 \pm 0.11$ & $1.67 \pm 0.11^{1,2}$ & $2.31 \pm 0.14$ & $2.31 \pm 0.18$ & $1.95 \pm 0.13^{1,2}$ \\
\hline$A L T(\mu k a t / l / m l)$ & $0.247 \pm 0.02$ & $0.299 \pm 0.03$ & $0.299 \pm 0.03$ & $0.429 \pm 0.04^{*, 1,2}$ & $0.329 \pm 0.05$ & $0.284 \pm 0.02$ & $0.325 \pm 0.05^{\mathrm{x}}$ \\
\hline$A S T(\mu k a t / l / m l)$ & $0.287 \pm 0.02$ & $0.338 \pm 0.02$ & $0.405 \pm 0.03 *$ & $0.415 \pm 0.03^{*, 1}$ & $0.370 \pm 0.03 *$ & $0.451 \pm 0.043 *$ & $0.352 \pm 0.03^{\mathrm{x}}$ \\
\hline$G G T(\mu k a t / l / m l)$ & $0.347 \pm 0.12$ & $0.135 \pm 0.02$ & $0.163 \pm 0.03$ & $0.323 \pm 0.04^{1,2}$ & $0.173 \pm 0.02$ & $0.180 \pm 0.03$ & $0.242 \pm 0.03$ \\
\hline fT4 (pmol/l) & $13.49 \pm 1.35$ & $11.52 \pm 0.93$ & --- & -- & $11.84 \pm 0.39$ & -- & --- \\
\hline TSH (pmol/l) & $2.51 \pm 0.86$ & $1.76 \pm 0.18$ & --- & --- & $1.75 \pm 0.25$ & --- & --- \\
\hline Insulin $(p g / m l)$ & $123.1 \pm 23.93$ & $393.5 \pm 47.4^{*}$ & $414.3 \pm 53.4^{*}$ & $339.8 \pm 45.1^{*}$ & $776.6 \pm 211.9 *$ & $813.0 \pm 187.5^{*}$ & $258.2 \pm 30.8^{1,2}$ \\
\hline Leptin $(p g / m l)$ & $4.78 \pm 1.34$ & $20.28 \pm 2.12 *$ & $23.13 \pm 2.70 *$ & $25.20 \pm 4.75^{*}$ & $27.65 \pm 4.70 *$ & $32.10 \pm 5.82 *$ & $16.05 \pm 4.34^{1,2}$ \\
\hline
\end{tabular}

V1: 28-32 weeks of gestation, V2: 36-38 weeks of gestation, V3: after delivery. ALT: alanine aminotransferase, AST: aspartate aminotransferase, GGT: $\gamma$-glutamyltransferase. ALP: alkaline phosphatase. Values are Mean $\pm \mathrm{SEM} . * \mathrm{p}<0.05$ vs. non-pregnant women, One way ANOVA/ANOVA on Ranks, $1 \mathrm{p}<0.05$ vs. V1; One Way repeated measures ANOVA/One way repeated measures ANOVA on Ranks, ${ }^{2} p<0.05$ vs. V2; One Way repeated measures ANOVA/One way repeated measures ANOVA on Ranks, ${ }^{\mathbf{x}} p<0.05$ vs. pregnant women with GDM; unpaired $t$-test or Mann-Whitney Rank Sum Test.

The effect of pregnancy and gestational diabetes mellitus on systemic levels of IGFs and IGFBPs

IGF-1 levels were higher in pregnant women compared to non-pregnant women and decreased after delivery. IGF-2 levels were increased only in pregnant women with GDM at 36 weeks of pregnancy compared to non-pregnant women. IGF-2 levels in pregnant women with GDM increased after delivery compared to pregnant women without GDM. IGFBP-1 levels decreased after delivery compared to both $\mathrm{V} 1$ and $\mathrm{V} 2$ in both groups of pregnant women. IGFBP-3 was higher in pregnant women compared to non-pregnant women and decreased after delivery. IGFBP-4 was elevated in pregnant women without GDM compared to GDM. IGFBP-6 levels increased after delivery only in pregnant women without GDM. IGFBP-7 levels were decreased during pregnancy and increased after delivery in pregnant women without GDM (Fig. 1).

The IGF-1/IGFBP-3 ratio was increased only in pregnant women without GDM compared to non- pregnant women and decreased in both groups of pregnant women after delivery. The IGF-1/IGFBP-1 ratio increased after delivery in both groups of pregnant women.

Expression of mRNA of the IGFs in controls and pregnancies with and without GDM

In non-pregnant women, IGF-1 mRNA expression was lower in SAT compared to VAT. Also IGF-1 mRNA expression in SAT of non-pregnant women was lower compared to SAT of both groups of pregnant women. In pregnant women with GDM, IGF-1R mRNA expression was lower in SAT and VAT compared to nonpregnant women and pregnant women without GDM. IGF-2 mRNA expression in non-pregnant women was higher in VAT compared to SAT. IGF-2 mRNA expression in VAT in non-pregnant women was increased compared to pregnant women with GDM. IGF-2R mRNA expression in pregnant women with GDM was lower in VAT compared to SAT and IGF-2R mRNA 

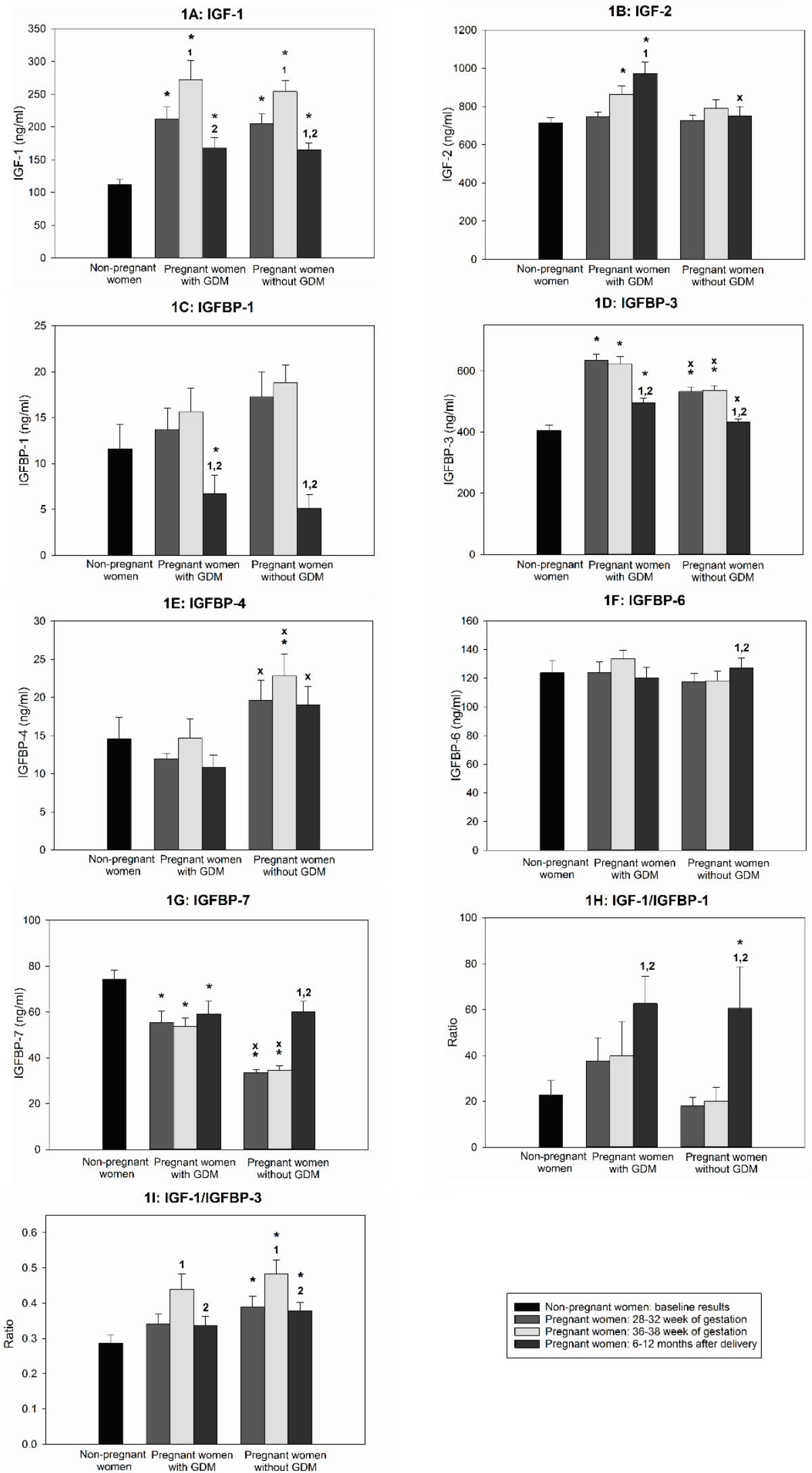

Fig. 1. Serum levels of IGFs and their binding proteins: the influence of pregnancy and gestational diabetes mellitus. IGF: insulin-like growth factor, IGFBP: IGF binding protein, GDM: gestational diabetes mellitus, V1: 28-32 weeks of gestation, V2: 36-38 weeks of gestation, V3: after delivery. Values are Mean \pm SEM. ${ }^{*} p<0.05$ vs. non-pregnant women, One way ANOVA/ANOVA on Ranks, ${ }^{1} p<0.05$ vs. V1; One Way repeated measures ANOVA/One way repeated measures ANOVA on Ranks, $2 \mathrm{p}<0.05$ vs. V2; One way repeated measures ANOVA/One way repeated measures ANOVA on Ranks, ${ }^{\mathbf{x}} \mathrm{p}<0.05$ vs. pregnant without GDM; unpaired $t$-test or Mann-Whitney Rank Sum Test 
expression in VAT in pregnant women with GDM was lower compared to non-pregnant women and pregnant women without GDM. IGFBP-2 mRNA expression in non-pregnant women was decreased in VAT compared to SAT and was decreased in VAT in non-pregnant women compared to both groups of pregnant women, respectively. IGFBP-3 mRNA expression in nonpregnant women in SAT was lower compared to both pregnant women with and without GDM. IGFBP-4 mRNA expression in non-pregnant women and pregnant women with GDM was lower in VAT compared to SAT, while pregnant women without GDM had higher mRNA expression in VAT compared to pregnant women with GDM. IGFBP-5 mRNA expression in non-pregnant women was lower in SAT compared to VAT and IGFBP-5 mRNA expression in non-pregnant women was lower in SAT compared to pregnant women with and without GDM. IGFBP-6 mRNA expression in nonpregnant women was lower in VAT compared to SAT. IGFBP-7 mRNA expression in non-pregnant women was higher in VAT compared to SAT and was higher in VAT compared to pregnant women without GDM (Fig. 2).

\section{Relationship of IGFs and IGFBPs to other studied parameters}

IGF-1 positively correlated with total cholesterol $(\mathrm{R}=0.438, \quad \mathrm{p}=0.012), \quad \mathrm{HDL}$ cholesterol $\quad(\mathrm{R}=0.554$, $\mathrm{p}=0.002)$, insulin $(\mathrm{R}=0.511, \mathrm{p}<0.001)$ and leptin $(\mathrm{R}=0.675, \mathrm{p}<0.001)$ and negatively with creatinine $(\mathrm{R}=-0.426, \mathrm{p}=0.002)$, uric acid $(\mathrm{R}=-0.340, \mathrm{p}=0.026)$ and total bilirubin $(\mathrm{R}=-0.440, \mathrm{p}=0.002)$. IGFBP -1 positively correlated with AST $(\mathrm{R}=0.303, \mathrm{p}=0.031)$. IGFBP-3 positively correlated with $\mathrm{BMI}(\mathrm{R}=0.570, \mathrm{p}<0.001)$, ALP $(\mathrm{R}=0.477, \mathrm{p}=0.025)$, insulin $(\mathrm{R}=0.480, \mathrm{p}=0.001)$ and leptin $(\mathrm{R}=0.619, \mathrm{p}<0.001)$ and inversely with urea $(\mathrm{R}=-0.283, \mathrm{p}=0.044)$, creatinine $(\mathrm{R}=-0.562, \mathrm{p}<0.001)$ and total bilirubin $(\mathrm{R}=-0.641, \mathrm{p}<0.001)$. IGFBP-4 positively correlated with ALT $(\mathrm{R}=0.315, \mathrm{p}=0.026)$ and AST $(\mathrm{R}=0.315, \mathrm{p}=0.026)$. IGFBP-7 positively correlated with creatinine $(\mathrm{R}=0.366, \mathrm{p}=0.009)$, total bilirubin $(\mathrm{R}=0.361$, $\mathrm{p}=0.009)$ and negatively with $\operatorname{ALP}(\mathrm{R}=-0.662, \mathrm{p}=0.001)$, total cholesterol $(\mathrm{R}=-0.409, \mathrm{p}=0.018)$, HDL cholesterol $(\mathrm{R}=-0.428, \mathrm{p}=0.017)$ and leptin $(\mathrm{R}=-0.367, \mathrm{p}=0.008)$.

\section{Discussion}

Besides growth-promoting effects, the IGF-1 system possesses also significant metabolic effects with glucose metabolism regulation belonging to most important ones. It acts at systemic, paracrine and autocrine levels (Clemmons 2006) and its local and systemic changes could significantly modulate glucose metabolism. Here, we for the first time report changes in the IGF-1 system in gestational diabetes mellitus (GDM) at both systemic and tissue levels.

IGF-1 and IGF-2 levels in systemic circulation were higher in pregnant compared to non-pregnant women and did not significantly differ in women with GDM relative to healthy pregnant controls. This finding is in accordance with the majority of previous studies (Kubota et al. 1992, Wilson et al. 1982, Funakoshi et al. 1990), However, Zhu et al. (2016) reported significantly higher serum levels of IGF-1 throughout the pregnancy in women with GDM as compared to healthy pregnant controls.

In our study, we showed different dynamics of serum IGF-1 and IGF-2 during pregnancy. Whilst in both pregnant women with and without GDM, IGF-1 serum levels were increasing during pregnancy and fell significantly after delivery, the increase of IGF-2 serum levels continued in pregnant women with GDM beyond pregnancy being at 6-12 months after delivery significantly higher compared to non-GDM group. This finding is hard to explain and is in contrast with the data of Yan-Jun et al. (1996) who described prompt drop of IGF-1 as well as IGF-2 serum levels after delivery in normal and diabetic women suggesting placental factors as contributors of the increased pregnancy levels.

Similarly, IGFBP-3, the main IGF-binding protein in serum that serves as circulating reservoir for IGF-1, was significantly increased in both groups of pregnant comparing to non-pregnant women and its serum levels decreased throughout pregnancy and after delivery. IGFBP-3 serum levels were significantly higher in women with GDM as compared to healthy pregnant controls. One can hypothesize that higher IGFBP-3 levels in women with GDM could partly contribute to decreased IGF-1 bioavailability in GDM subjects. Indeed, healthy pregnant women had significantly increased serum IGF-1/IGFBP-3 ratio (compared to non-pregnant women), while GDM women did not. Increased serum levels of IGFBP-3 have been previously reported in insulin resistant and type 2 diabetes subjects (Frystyk et al. 1999) and were suggested as a risk factor for development of metabolic disturbances (Rajpathak et al. 2009).

IGFBP-1 is an important and variable modulator of the IGF-1 bioavailability. Since its liver production is inversely regulated by insulin concentration in portal 


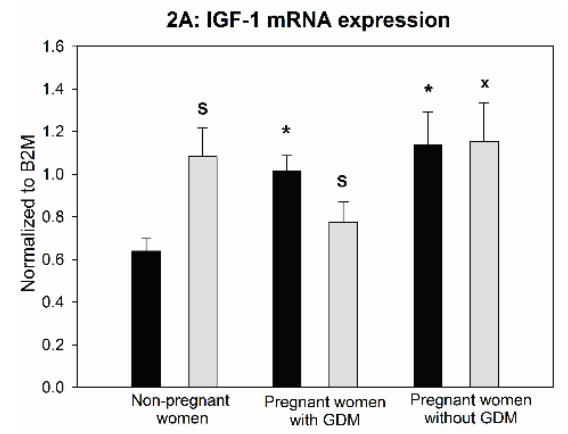

2C: IGF-1R mRNA expression

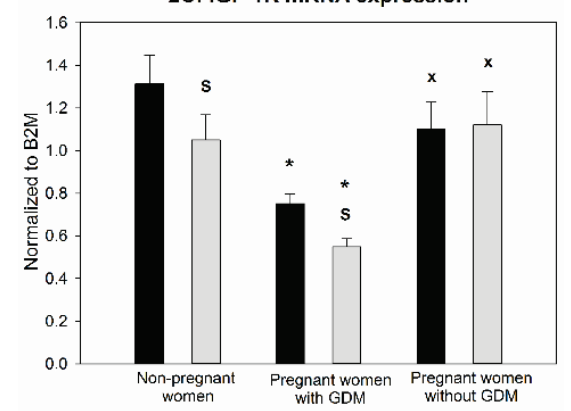

2E: IGFBP-2 mRNA expression

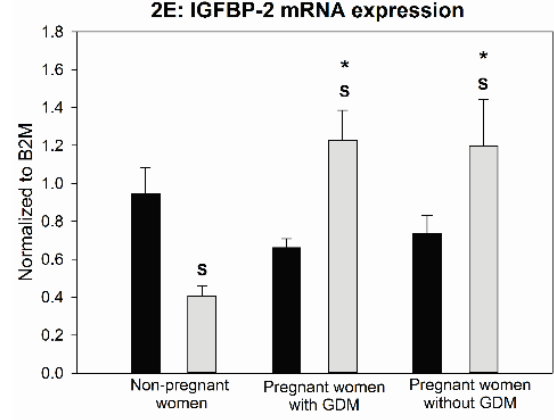

2G: IGFBP-4 mRNA expression

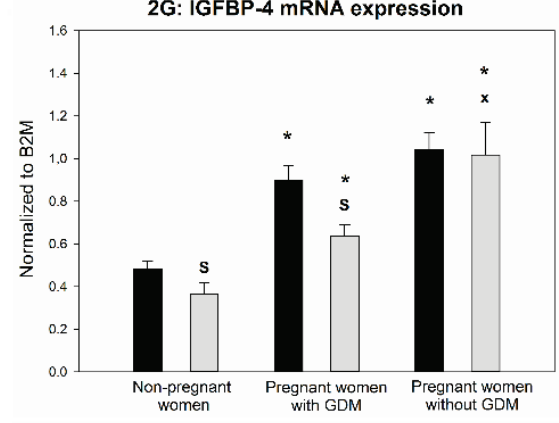

21: IGFBP-6 mRNA expression

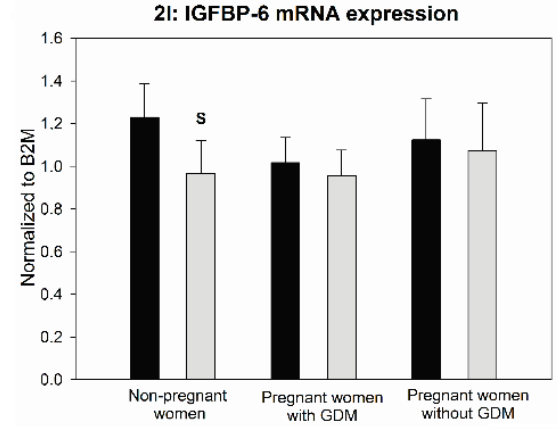

2B: IGF-2 mRNA expression

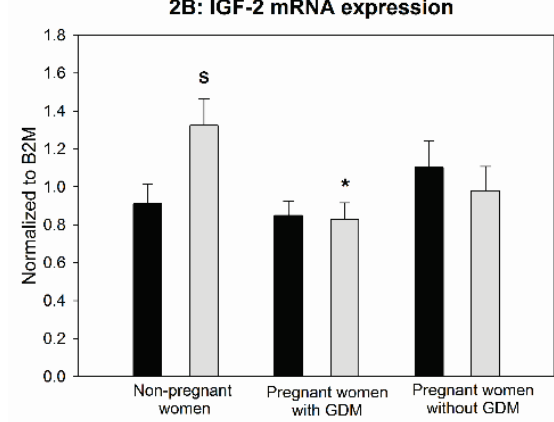

2D: IGF-2R mRNA expression

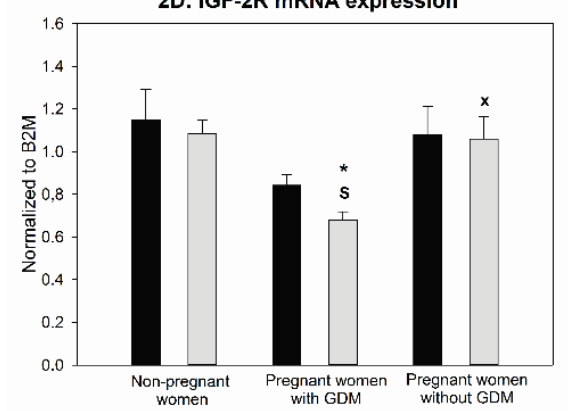

2F: IGFBP-3 mRNA expression

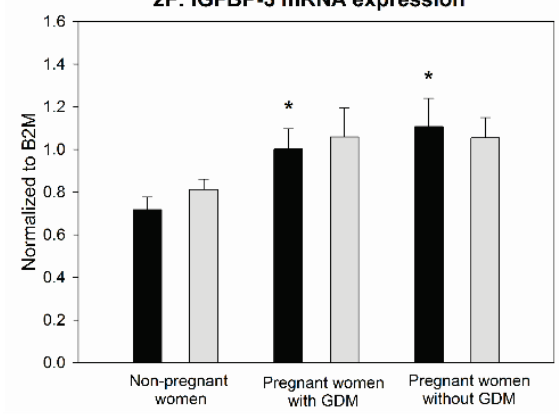

2H: IGFBP-5 mRNA expression

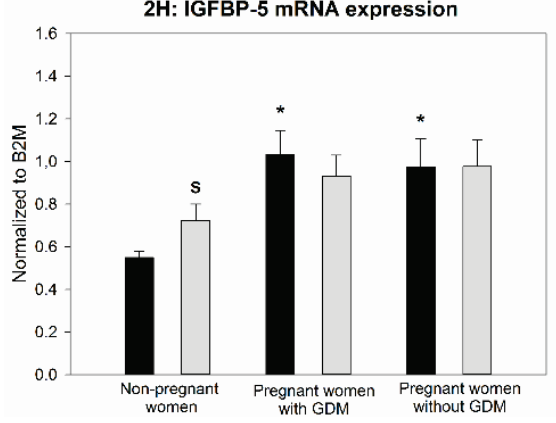

2J: IGFBP-7 mRNA expression

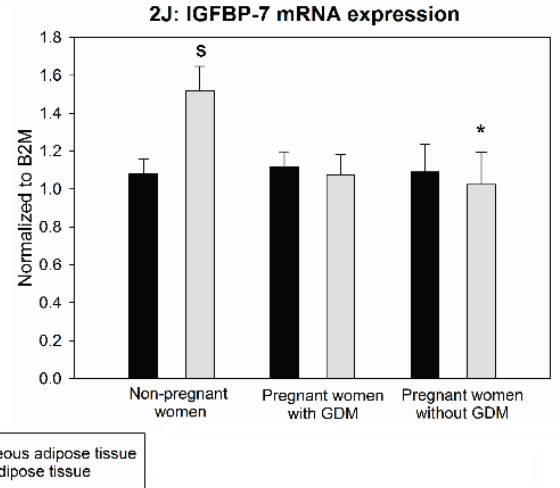

Fig. 2A-J. Tissue mRNA expression of IGFs, their receptors and IGFBPs: the influence of pregnancy and gestational diabetes mellitus. IGF: insulin-like growth factor, IGFBP: IGF binding protein, IGFR: receptor for IGF. $* p<0.05$ vs. non-pregnant women, One way ANOVA/ANOVA on Ranks, ${ }^{\mathbf{s}} \mathrm{p}<0.05$ vs. subcutaneous adipose tissue, paired test Wilcoxon Signed-Rank, $\mathbf{x}_{\mathrm{p}}<0.05$ vs. pregnant women with GDM; unpaired $t$-test or Mann-Whitney Rank Sum Test. 
blood, we would expect its lower levels in women with GDM. Surprisingly, they were comparable between pregnant women with and without GDM and even nonpregnant women. Our results are in contrast with the study of Liao et al. (2017), which reported slight but significant decrease in IGFBP-1 levels in GDM. However, several experimental studies reported increased IGFBP-1 serum levels also in association with insulin resistant conditions (Han et al. 2006, Pao et al. 1992, Luo et al. 1992) and Rajpathak et al. suggested a gradual increase of IGFBP-1 levels with increasing insulin resistance (Rajpathak et al. 2009). By contrast, significant decrease of IGFBP-1 serum levels after delivery in our study might be associated with the decrease of insulin resistance and improvement of insulin inhibitory action on IGFBP-1 levels after delivery.

Being aware of the complex action of the IGF system and the importance of its activity at the tissue level we originally designed this study to explore its changes at systemic and local levels in the same subjects. Looking at tissue expression we found significantly lower mRNA expressions of IGF-1, IGF-1R and IGF-2R in VAT of pregnant women with GDM in comparison with healthy pregnant women. The mRNA expression of IGF-1R was significantly lower also in SAT of GDM subjects. Taken together we can conclude that the bioactivity of the IGF-1 system in adipose tissue is lower in pregnant women with GDM in comparison with healthy pregnant females. Abnormalities in local IGF-1R and IGFBP-3 expression in SAT (Yamada et al. 2010) and decreased mRNA expression of IGF-1 and IGF-1R have also been found in SAT of type 2 diabetes subjects and a possible association with the decreased differentiation capacity of adipose tissue and subsequent ectopic lipid accumulation contributing to insulin resistance has been proposed (Touskova et al. 2012).

IGFBP-4 has been identified as a potential key factor in adipose tissue expansion in response to high-fat diet in mice (Gealekman et al. 2014). Rojas-Rodriguez et al. (2015) found decreased IGFBP-5 in adipose tissue in GDM and suggested that adipose tissue expandability is decreased in GDM. We found significantly decreased IGFBP-4 mRNA expression levels in VAT as well as its serum levels in women with GDM which is in agreement with the reduced expandability hypothesis.

In conclusion, in our study we found higher concentrations of components of IGF-1 system in pregnant women comparing to non-pregnant controls at the systemic level without significant differences between pregnant subjects with or without GDM. In contrast, mRNA expressions of IGF-1 system components in subcutaneous and visceral adipose tissue were decreased suggesting its attenuated activity and action in adipose tissue. A decrease in local activity of the IGF system may be connected to reduction of insulin sensitivity and contribute to the development of gestational diabetes.

\section{Conflict of Interest}

There is no conflict of interest.

\section{Acknowledgements}

Supported by AZV 15-27630A.

\section{References}

BLÜHER S KJ, KIESS W, BUTENANDT O: Insulin-like growth factor I, growth hormone and insulin in white adipose tissue. Best Pract Res Clin Endocrinol Metab 19: 577-587, 2005.

BUCHANAN TA, XIANG AH: Gestational diabetes mellitus. J Clin Invest 115: 485-491, 2005.

CATALANO PM, KIRWAN JP, HAUGEL-DE-MOUZON S, KING J: Gestational diabetes and insulin resistance: role in short- and long-term implications for mother and fetus. J Nutr 133 (5 Suppl 2): 1674-1683, 2003.

CHAN K, SPENCER EM: General aspects of insulin-like growth factor binding proteins. Endocrine 7: 95-97, 1997.

CHEN L, MAGLIANO DJ, ZIMMET PZ: The worldwide epidemiology of type 2 diabetes mellitus--present and future perspectives. Nat Rev Endocrinol 8: 228-236, 2011.

CLEMMONS DR: Involvement of insulin-like growth factor-I in the control of glucose homeostasis. Curr Opin Pharmacol 6: 620-625, 2006.

CLEMMONS DR: Metabolic actions of insulin-like growth factor-I in normal physiology and diabetes. Endocrinol Metab Clin North Am 41: 425-43, 2012.

FRYSTYK J, SKJAERBAEK C, VESTBO E, FISKER S, ORSKOV H: Circulating levels of free insulin-like growth factors in obese subjects: the impact of type 2 diabetes. Diabetes Metab Res Rev 15: 314-322, 1999. 
FUNAKOSHI T, UEDA Y, KOBAYASHI A, MORIKAWA H, MOCHIZUKI M: Studies on insulin-like growth factors (IGF-I, -II) and their binding proteins in normal human pregnancy. Folia Endocrinol Japon 66: 688-699, 1990.

GEALEKMAN O, GURAY K, CHOUINARD M, STRAUBHAAR J, THOMPSON M, MALKANI S, HARTIGAN C, CORVERA S: Control of adipose tissue expandability in response to high fat diet by the insulin-like growth factor-binding protein-4. J Biol Chem 289: 18327-18338, 2014.

HAN HJ, KANG CW, PARK SH: Tissue-specific regulation of insulin-like growth factors and insulin-like growth factor binding proteins in male diabetic rats in vivo and in vitro. Clin Exp Pharmacol Physiol 33: 1172-1179, 2006.

HOLT RI, SIMPSON HL, SONKSEN PH: The role of the growth hormone-insulin-like growth factor axis in glucose homeostasis. Diabet Med 20: 3-15, 2003.

INTERNATIONAL ASSOCIATION OF DIABETES AND PREGNANCY STUDY GROUPS CONSENSUS PANEL, METZGER BE, GABBE SG, PERSSON B, BUCHANAN TA, CATALANO PA, DAMM P, DYER AR, LEIVA AD, HOD M, KITZMILER JL, LOWE LP, MCINTYRE HD, OATS JJ, OMORI Y, SCHMIDT MI: International association of diabetes and pregnancy study groups recommendations on the diagnosis and classification of hyperglycemia in pregnancy. Diabetes Care 33: 676-682, 2010.

KUBOTA T, KAMADA S, TAGUCHI M, ASO T: Determination of insulin-like growth factor-2 in feto-maternal circulation during human pregnancy. Acta Endocrinol 127: 359-365, 1992.

LANGER O, YOGEV Y, MOST O, XENAKIS EM: Gestational diabetes: the consequences of not treating. Am J Obstet Gynecol 192: 989-997, 2005.

LEWITT MS: Role of the insulin-like growth factors in the endocrine control of glucose homeostasis. Diabetes Res Clin Pract 23: 3-15, 1994.

LIAO S, VICKERS MH, TAYLOR RS, FRASER M, MCCOWAN LME, BAKER PN, PERRY JK: Maternal serum placental growth hormone, insulin-like growth factors and their binding proteins at 20 weeks' gestation in pregnancies complicated by gestational diabetes mellitus. Hormones (Athens) 6: 282-290, 2017.

LIU KS, WANG CY, MILLS N, GYVES M, ILAN J: Insulin-related genes expressed in human placenta from normal and diabetic pregnancies. Proc Natl Acad Sci U S A 82: 3868-3870, 1985.

LIVINGSTONE C: IGF2 and cancer. Endocr Relat Cancer 20: R321-R339, 2013.

LUO J, MURPHY LJ: Differential expression of the insulin-like growth factor binding proteins in spontaneously diabetic rats. $J$ Mol Endocrinol 8: 155-163, 1992.

MAURAS N, HAYMOND MW: Are the metabolic effects of GH and IGF-I separable? Growth Horm IGF Res 15: 19-27, 2005.

MOSES AC, YOUNG SC, MORROW LA, O'BRIEN M, CLEMMONS DR: Recombinant human insulin-like growth factor I increases insulin sensitivity and improves glycemic control in type II diabetes. Diabetes 45: 91-100, 1996.

PAO CI, FARMER PK, BEGOVIC S, GOLDSTEIN S, WU GJ, PHILLIPS LS: Expression of hepatic insulin-like growth factor-I and insulin-like growth factor-binding protein-1 genes is transcriptionally regulated in streptozotocin-diabetic rats. Mol Endocrinol 6: 969-977, 1992.

QIU C, VADACHKORIA S, MERYMAN L, FREDERICK IO, WILLIAMS MA: Maternal plasma concentrations of IGF-1, IGFBP-1, and C-peptide in early pregnancy and subsequent risk of gestational diabetes mellitus. Am J Obstet Gynecol 193: 1691-1697, 2005.

RAJPATHAK SN, GUNTER MJ, WYLIE-ROSETT J, HO GY, KAPLAN RC, MUZUMDAR R, ROHAN TE, STRICKLER HD: The role of insulin-like growth factor-I and its binding proteins in glucose homeostasis and type 2 diabetes. Diabetes Metab Res Rev 25: 3-12, 2009.

ROJAS-RODRIGUEZ R, LIFSHITZ LM, BELLVE KD, MIN SY, PIRES J, LEUNG K, BOERAS C, SERT A, DRAPER JT, CORVERA S, MOORE SIMAS TA: Human adipose tissue expansion in pregnancy is impaired in gestational diabetes mellitus. Diabetologia 58: 2106-2114, 2015.

TORRES ALEMAN I: Role of insulin-like growth factors in neuronal plasticity and neuroprotection. Adv Exp Med Biol 567: 243-258, 2005. 
TOUSKOVA V, TRACHTA P, KAVALKOVA P, DRAPALOVA J, HALUZIKOVA D, MRAZ M, LACINOVA Z, MAREK J, HALUZIK M: Serum concentrations and tissue expression of components of insulin-like growth factor-axis in females with type 2 diabetes mellitus and obesity: the influence of very-low-calorie diet. $\mathrm{Mol}$ Cell Endocrinol 361: 172-178, 2012.

WABITSCH M, HAUNER H, HEINZE E, TELLER WM: The role of growth hormone/insulin-like growth factors in adipocyte differentiation. Metabolism 44 (10 Suppl 4): 45-49, 1995.

WILSON DW, BENNETT A, ADAMSON GD, NAGASHIMA RJ, LIU F, DENATALE ML, HINTZ RL, ROSENFELD RG: Somatomedins in pregnancy: A crossectional study of insulin-like growth factors I and II and somatomedin peptide content in normal pregnancies. J Clin Endocrinol Metab 55: 858-861, 1982.

YAN-JUN L, TSUSHIMA T, MINEI S, SANAKA M, NAGASHIMA T, YANAGISAWA K, OMORI Y: Insulin-like growth factors (IGFs) and IGF-binding proteins (IGFBP-1, -2 and -3) in diabetic pregnancy: relationship to macrosomia. Endocr J 43: 221-231, 1996.

YAMADA PM, MEHTA HH, HWANG D, ROOS KP, HEVENER AL, LEE KW: Evidence of a role for insulin-like growth factor binding protein (IGFBP)-3 in metabolic regulation. Endocrinology 151: 5741-5750, 2010.

ZHU Y, MENDOLA P, ALBERT PS, BAO W, HINKLE SN, TSAI MY, ZHANG C: Insulin-like growth factor axis and gestational diabetes mellitus: a longitudinal study in a multiracial cohort. Diabetes 65: 3495-3504, 2016.

ZHU Y, ZHANG C: Prevalence of gestational diabetes and risk of progression to type 2 diabetes: a global perspective. Curr Diab Rep 16: 7, 2016. 